\title{
Ecological impact and population status of non-native bees in a Brazilian urban environment
}

\author{
Letícia Vanessa Grafa* (D), Rafael Dudeque Zennib ${ }^{(1)}$, Rodrigo Barbosa Gonçalves ${ }^{a}$ (D) \\ aUniversidade Federal do Paraná, Departamento de Zoologia, Curitiba, PR, Brasil. \\ ${ }^{b}$ Universidade Federal de Lavras, Departamento de Biologia, Lavras, MG, Brasil.
}

\section{A R T I C L E I N F O}

\section{Article history:}

Received 14 January 2020

Accepted 19 April 2020

Available online 08 June 2020

Associate Editor: Eduardo Almeida

\section{Keywords:}

Apidae

Apoidea

Invasion

Meliponiculture

Pollinator.

\begin{abstract}
A B S T R A C T
The introduction of species is an important global threat to native ecosystems and yet little is known about invasion risks of non-native bees. Moreover, urbanization is increasing rapidly around the world with impact on the bee fauna. The city of Curitiba (Brazil) could be considered a model system for studies under this scope, with historical samplings and monitoring programs since the 1940s. This paper aims to quantify the current ecological impact of the non-native bee species present in Curitiba by using an integrative measure of impact and to define their current population status by classifying them into a unified framework for biological invasions. Ten sites were actively sampled in the metropolitan area of Curitiba during ten months. In addition to Apis mellifera Linnaeus, 1758, we found two others non-native species, Anthidium manicatum (Linnaeus, 1758) and Melipona scutellaris Latreille, 1811. None of them changed the native bee community structure, but they got different values of impact due to their ranges and abundances. While the honeybee is a known invasive species, A. manicatum was also considered invasive and has persisted in the city since the 1940 s, interacting with the non-native plant Leonurus japonicus Houtt. M. scutellaris, a cultivated stingless bee species, had its first record for the city and fits the casual non-native category. We suggest monitoring the non-native bee species and actions centered on beekeepers to avoid future illegal introductions. The honey production or hobby interest on stingless bees can offer additional obstacles for species conservation when decoupled of scientific knowledge.
\end{abstract}

\section{Introduction}

There are at least 80 bee species recorded as introduced somewhere in the world (Russo, 2016), and these non-native bee species per se have been considered one of the main threats to native bees (Freitas et al., 2009). However, the quantification of bee invasion impacts on the whole biota is not an easy task, as for other organisms (Paini, 2004; Didham et al., 2007). Impact is a complex invasion metric beclouded by a mix of ecological factors (i.e. population dynamics and species interactions), economic and social importance of non-native species, and judgments of "good," "bad," "helpful," and "harmful" traits (Simberloff et al., 2013). There has been a remarkable effort in the last decades to decompose these impacts in order to get a better understanding of them. The vast majority of studies on bees have focused on Apis mellifera Linnaeus, 1758 (e.g. Santos et al., 2012; Valido et al., 2019) and Bombus Latreille, 1802 , and limited attention has been given to other non-native species (Russo, 2016). Given that bees are an immensely diverse group in terms of feeding habits, social, and ecological behaviors, it is unlikely the impacts attributed to A. mellifera and Bombus can be extended to other groups of bees (i.e. solitary or stingless bees). Thus, it is necessary to evaluate the impacts of non-native bee species on native ecosystems in terms of their species-specific biology and population dynamics so that the relative weight of life-history traits, population dynamics, and ecological interactions are clearly distinguished.

Several bee species have been intentionally introduced to the Americas, and the most remarkable case is the Africanized honeybee A. mellifera. The subspecies $A$. mellifera scutellata was brought to Brazil in 1956 and it has since spread to most of the continent, except the extremes southern and northern parts of South and North America, respectively (Schneider et al., 2004; Santos and Mendes, 2016). In spite of the public concern about $A$. mellifera declines worldwide (VanEngelsdorp et al., 2009), its introduced populations can offer risks to plant reproduction as well as to native bee species by competing with flower resources and by spreading diseases (Santos et al., 2012;

\footnotetext{
* Corresponding author.

E-mail: leticiagraf@yahoo.com.br (L.V.Graf)
} 
Geldmann and González-Varo, 2017). Valido et al. (2019) found that A. mellifera reduces the diversity of wild pollinators and have a negative impact on the interaction links in the pollination networks, but in contrast Moritz et al. (2005) found no evidences that feral honeybees can actually cause the extinction of native bees. Cane and Tepedino (2017) estimated that an apiary with 40 colonies collects the amount of pollen equivalent to four million wild bees' larval provisions, an undeniable influence on resource sharing.

With regard to other non-native bee species, little is known about their impact on the environment and on native bees. Some species were introduced for crop pollination, for example Megachile rotundata (Fabricius, 1787), used as the pollinator of the alfalfa (Medicago sativa L.) in the United States (Pitts-Singer and Cane, 2011). In South America, the bumble bees Bombus ruderatus (Fabricius, 1775) and Bombus terrestris Linnaeus, 1758 were introduced in Chile for crop pollination and have become invasive in both Chile and Argentina (Aizen et al., 2018). Bees have also been introduced accidentally, for example, in Brazil there are three known cases: Anthidium manicatum (Linnaeus, 1758), Hylaeus punctatus (Brullé, 1832), and Lithurgus ruberi Ducke, 1907 (Strange et al., 2011; Silva et al., 2014; Russo, 2016). Among the accidentally introduced bees in the Americas, A. manicatum (Megachilinae, Anthidiini) has the largest distribution. It is a solitary bee originally from Europe, northern Africa and western Asia (Gibbs and Sheffield, 2009; Strange et al., 2011) and now occurs in several Brazilian states (Fig. 1c) (Urban and Moure, 2012) as well as in Argentina and Uruguay (Moure and Urban, 1964). In North America, the first record of this species is from the 1960s, in New York, where it was introduced by an accidental event, independent from that happened in South America (Gibbs and Sheffield, 2009). A. manicatum is called the wool carder bee, as the female collects trichomes from leaves and stems for nest construction, especially from Lamiaceae plants (Miller et al., 2002; Michener, 2007). Its male is known to aggressively defend floral territories attacking heterospecific pollinators, causing resource exclusion (Graham et al., 2019).

Beekeepers and researchers have also introduced stingless bee species that are native to some parts of South America to others regions of the continent where they are not native. This information is not usually scientifically reported, even though it is possible, in Brazil, to buy online stingless bees' hives from any region of the country. For instance, Melipona (Michmelia) scutellaris Latreille, 1811 (Apinae, Meliponini), known as "Uruçu nordestina", is an eusocial native bee that occurs in northeastern Brazil (Camargo and Pedro, 2013) and is broadly used in meliponiculture (Evangelista-Rodrigues et al., 2005; Alves et al., 2012). There are records for the species outside its natural range for Goiás, Minas Gerais, and São Paulo (Fig. 1e). In Uberlândia (Minas Gerais), it hybridizes with its closely related species, Melipona (Michmelia) capixaba Moure \& Camargo, 1994 (Nascimento et al., 2000), which represents an additional genetic threat to native species, especially to endangered ones, and consequently to biodiversity (Wolf et al., 2001; Todesco et al., 2016). Both species are in the Brazilian red list (Silveira et al., 2008; ICMBio, 2016).

A recent study showed that urbanization is correlated with increased prevalence of non-native bees, demonstrating that cities can be suitable environments for bee invasion, attributable to trait-matching between characteristics of some exotic bees, such as cavity-nesting habit, and abundance in urban environments (Fitch at al., 2019). Besides this study, the introduction of non-native bee species on highly anthropic environments, such as cities, is not well documented. This is a crucial topic when we consider that currently $54 \%$ of the human population lives in cities and is expected to rise to 66\% approximately in 2050 (United Nations, 2018). The city of Curitiba, capital of the State of Paraná, located in southern Brazil, has one of the largest metropolitan areas in the country, with a population of almost three million people (IBGE, 2017).
Owing to historical bee samplings dating from the 1940s, and three monitoring programs since the 1960s, there is relevant information on the historical bee fauna and on the arrival of non-native species to the city. These monitoring programs have already shown a decline of 30\% in species richness and abundance between 1975 and 1993 in one monitoring site (Taura and Laroca, 2001), a decline of $22 \%$ in bee richness in a second site after 40 years of study (Martins et al., 2013), and the disappearance of almost half of the species during a period of 34 years in a third site (Cardoso and Gonçalves, 2018).

Considering that urbanization is increasing rapidly with impact over the environment and is recognized as an important factor for the loss of biodiversity (Kowarik, 2011; Fragkias et al., 2013; Deguines et al., 2016), along with the lack of information on non-native bees and their impacts in urban ecosystems, our goals here were to: 1 . quantify the current ecological impact of the three non-native bee species present in Curitiba ( $A$. manicatum, A. mellifera and M. scutellaris) by using a integrative measure of impact proposed by Parker et al. (1999), in order to try to disentangle the difficult question of measuring the impacts of non-native species; 2 . merge our data with literature distributional records to define the current population status of these non-native bee species by classifying them under the unified framework for biological invasions proposed by Blackburn et al. (2011).

\section{Material and methods}

\section{Site descriptions}

We sampled ten sites in the metropolitan area of Curitiba (Sate of Paraná, southern Brazil), where the climate is subtropical (average temperature, summer: $22^{\circ} \mathrm{C}$, winter: $17^{\circ} \mathrm{C}$, average rainfall: $1480 \mathrm{~mm}$; INMET- Instituto Nacional de Meteorologia) and original plant phytophysiognomies are a mix of Araucaria forests and natural grasslands within the Atlantic Forest ecoregion (Zonta et al., 2012). The ten sampling sites were distributed in five public parks, a University Campus site, three Army protected areas and the Curitiba International Airport (Table S1 of the Supplementary material). All sampling sites are inside the urban matrix and at least one and a half kilometers of distance apart, sufficient to guarantee site independency for bee studies (Ferreira et al., 2015).

\section{Data collection}

Bees were actively collected on flowers with insect nets following Sakagami et al. (1967) methodology. According to this protocol the sampling area is randomly searched for bees in flowers during the time of high bee activity, usually from 9h30 AM to 3h30 PM. One collector (LVG did all fieldwork) sampled one site per day. Each site was visited once per month, from August 2017 to May 2018, summing up to 600 hours of data collection. The main purpose of this sample design was to investigate the urban landscape effect on bee community. Specimens of $A$. mellifera were not collected, because this would jeopardize the methodology due the time-consuming collection and processing of honeybees.

In the laboratory, bees were sorted, pinned, and identified by comparison with collection specimens. Voucher bees are deposited in the collection Coleção Entomológica Pe. Jesus Santiago Moure (DZUP). Host plants were also collected, identified and vouchers are deposited in Herbário do Departamento de Botânica (UPCB). DZUP collection and SpeciesLink(http://www.splink.org.br/) were examined for records of $A$. manicatum and M. scutellaris in Brazil. Brazilian Bee-Plant Interactions Database (BBPID, http://abelhaseplantas.cria. 
org.br/) was checked for host records. Bipartite network from R package 'bipartite'v.2.08 (Dormann et al., 2008) was used to illustrate the bee and host plant sampled in this study.

\section{Statistical analyses}

The impact (I) of each species was determined following Parker et al., (1999) by multiplying metrics of range (R), abundance (A), and per capita effect in the studied region (E). Range was calculated as the percentage of sites where each species occurred. Abundance was calculated as the relative abundance of each non-native bee species from the total number of bees collected on the plant species where those non-native bees were sampled. In the case where the nonnative bee occurred in more than one area, the mean of the relative abundance was calculated. The per capita effect was calculated as the difference in bee diversity in the presence and the absence of each non-native species $\left(\Delta H^{\prime}\right)$. The Shannon diversity index $\left(H^{\prime}\right)$ was used as a metric for bee diversity at each plant species. When there was more than one plant species where the bee species occurred, the average of $\mathrm{H}^{\prime}$ was taken instead.

As we did not collect $A$. mellifera in the ten selected sites described above, we decided a posteriori to use a bee-plant web from a previous study conducted at the Curitiba International Airport (Martins et al., 2013) during the years 2004 and 2005, which followed the same sample methodology (Sakagami et al., 1967). The aim here is to use this data as an exploratory and new approach to try to disentangle the different invasion impacts (invasion range, species abundance and per capita effect) and not to compare the impact values among the three non-native species. It also serves the purpose of verifying the value of the formula itself as an integrative measure of impact for non-native species.

The relative abundance of $A$. mellifera was calculated from the total number of bees collected in the plants where bee species occurred, just as it was calculated for the other non-native bees. As we had data for only one site, we compared the bee diversity indexes among different plant species considering the plants where $A$. mellifera was detected and plants where it did not occur. Differently from the way we calculated the impact for the other two non-native species, where the $\Delta H^{\prime}$ was obtained from the same plant species from different areas, with and without their presence. We then used the non-parametric Wilcoxon Rank Sum to see if floral visitor diversities ( $\left.\mathrm{H}^{\prime}\right)$ in the presence and absence of the non-native species were different at $\alpha=0.05$. To confirm the statistical results for $A$. mellifera we also ran a generalized linear model (GLM) with an inverse link function and Gamma distribution to test floral visitor diversities ( $\mathrm{H}^{\prime}$ ) in the presence and absence of the non-native species.

Finally, the population status of each non-native species was defined following the unified framework for biological invasions (Blackburn et al., 2011). This classification takes into account the stages of the invasion process, considering that in each stage there are barriers that need to be overcome for a species or population to pass on to the next stage. It helps to determinate which management interventions each non-native species needs at the moment.

\section{Results}

From the 8,973 bees sampled in Curitiba, 15 specimens represented the non-native species A. manicatum (Fig. 1b) and M. scutellaris (Fig. 1d). Four specimens of $A$. manicatum (two females and two males) were sampled in three sites: one was caught on flight and the others were found only visiting Leonurus japonicus Houtt. (Lamiaceae). L. japonicus occurred in six sites, hosting eight bee species (Fig. 1a). Eleven specimens of $M$. scutellaris (ten females and one male) were caught at only one site, visiting five plant species, all native ornamental shrubs. These plants also occurred in other seven sites and hosted a total of 43 bee species, including both solitary and eusocial bees (Fig. 1a). A complete list of individual bees sampled in the six host plants is given in Table S2 and additional information is given in Table S3. This is the first record of M. scutellaris for Curitiba.

With regard to the relative abundance $\left(\mathrm{p}_{\mathrm{i}}\right)$ of the non-native bee species, $A$. manicatum was not a dominant species visiting $L$. japonicus. It was the second most abundant species (out of five), in the site where it was collected twice $\left(p_{i}=0.22\right)$, but it was the least abundant at the other two sites $\left(\mathrm{p}_{\mathrm{i}}=0.06\right.$ and $\left.\mathrm{p}_{\mathrm{i}}=0.25\right)$. Its mean relative abundance was 0.18 . M. scutellaris was the second most abundant species in the plants where it occurred $\left(\mathrm{p}_{\mathrm{i}}=0.21\right)$. The other most abundant bees at the same site (in the plants where $M$. scutellaris visited), were also stingless bees, Paratrigona subnuda Moure, $1947\left(\mathrm{p}_{\mathrm{i}}=0.24\right)$ and Melipona quadrifasciata Lepeletier, $1836\left(\mathrm{p}_{\mathrm{i}}=0.15\right)$. Regarding the bee-plant web of the Curitiba International Airport, $A$. mellifera was the most abundant bee species ( $59 \%$ from 3,061 individuals) including at the host plants where it was recorded $\left(\mathrm{p}_{\mathrm{i}}=0.61\right)$. As in the present study $A$. mellifera was observed everywhere in the studied region (in all ten sites), its range, for a purpose of an exploratory analysis of the formula proposed by Parker et al. (1999), was considered $100 \%$. Also, other field samples held in Curitiba also detected the presence of $A$. mellifera.

The Shannon diversity indexes for $A$. manicatum for presence and absence as plant visitor were $H^{\prime}=1.03 \pm 0.2 \mathrm{SE}$ and $\mathrm{H}^{\prime}=0.3 \pm 0.3 \mathrm{SE}$, respectively. By these values, bee diversity in $L$. japonicus was not significantly different in the presence of $A$. manicatum $(\mathrm{W}=8, \mathrm{P}=0.18$ ). Its per capita effect value $\left(\mathrm{E}=\Delta \mathrm{H}^{\prime}\right)$ is then 0.73 . For $M$. scutellaris the values were $H^{\prime}=1.85 \pm 0.3 \mathrm{SE}$ and $H^{\prime}=0.94 \pm 0.4 \mathrm{SE}$ for presence and absence respectively. Again, bee diversity was not significantly different $(\mathrm{W}=20, \mathrm{P}=0.14)$ and its per capita effect value is 0.91 . With both non-native bee species present in the system, the diversity was higher than without them and they did not have a clear per capita effect on the bee community $(P>0.05)$. It is important to note that in both cases the number of plants was low for both presences and absences $(\mathrm{n}<5)$. For $A$. mellifera, the mean bee diversity was obtained from the 56 plants species out of 100 . When $A$. was present, its value was $\mathrm{H}^{\prime}=1.01 \pm 0.1 \mathrm{SE}$ and when it was absent was $\mathrm{H}^{\prime}=0.73 \pm 0.1 \mathrm{SE}$ and its per capita effect value is 0.28 . Albeit not clearly different, bee diversity was slightly higher in the presence of $A$. mellifera $(\mathrm{W}=1003.5, \mathrm{P}=0.05$ for the Wilcoxon test and $\mathrm{t}=2.06, \mathrm{P}=0.04$ for the GLM). When the invasive bee was removed from the data for the analyses and only the native bee community matrix was analyzed, the effect became slightly stronger $(\mathrm{P}=0.04$ for the Wilcoxon test and $\mathrm{P}=0.02$ for the GLM).

The impact value of $A$. manicatum was therefore 3.94, and of $M$. scutellaris was 1.91 , whereas for $A$. mellifera the impact value was 17.08 (Table 1 ). As we interpreted the data of $A$. manicatum and $M$. scutellaris from ten different sites and comparing the Shannon diversity index differently from the way we are doing for $A$. mellifera, these values are not comparable among them, only between $A$. manicatum and M. scutellaris. Also, the impact value proposed here does not reflect whether or not there is a significant difference between them. In regard to the classification of the non-native species into the unified framework for biological invasions proposed by Blackburn et al. (2011), given the current literature knowledge on the distribution and biology of these species, added to the range and abundance values obtained in this study, their population status category were defined as: $\mathrm{E}$ (fully invasive) for A. mellifera, D2 (self-sustaining population distant from introduction point) for $A$. manicatum and B2 (in cultivation) for M. scutellaris. 

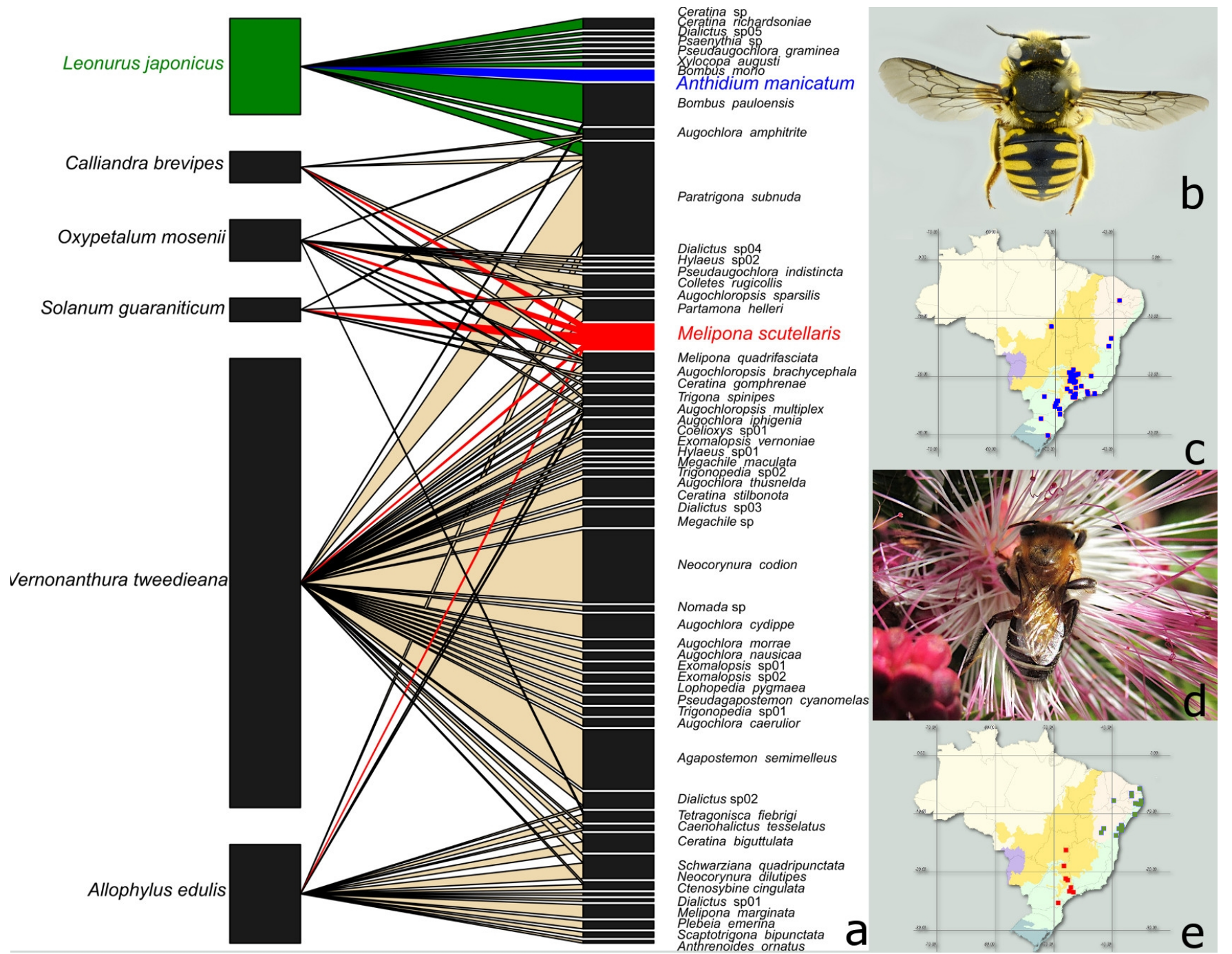

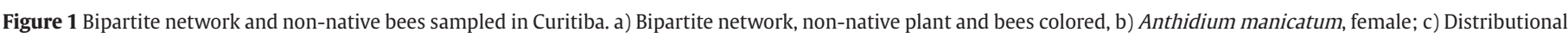
range of A. manicatum (SpeciesLink); d) Melipona scutellaris worker on Calliandra brevipes; e) Distributional range of M. scutellaris (SpeciesLink), natural records in green.

Table 1

Invasion metrics for Anthidium manicatum, Apis mellifera and Melipona scutellaris across 10 green urban areas in Curitiba, southern Brazil. Per capita effect is the mean H' for the floral bee visitors in the presence and absence of the non-native species. Impact was calculated following Parker et al. (1999) as I = R x A x E. Population statuses were categorized according to Blackburn et al. (2011).

\begin{tabular}{|c|c|c|c|c|c|}
\hline Non-native bee species & $\begin{array}{l}\text { Percentage of the number } \\
\text { of sites }(\mathrm{R})\end{array}$ & $\begin{array}{l}\text { Mean relative abundance } \\
\text { (A) }\end{array}$ & Per capita effect (E) & Impact value $(\mathrm{R} \times \mathrm{A} \times \mathrm{E})$ & Population status \\
\hline Anthidium manicatum & 30 & 0.18 & 0.73 & 3.94 & Invasive (D2) \\
\hline Apis mellifera & 100 & 0.61 & 0.28 & 17.08 & Invasive (E) \\
\hline Melipona scutellaris & 10 & 0.21 & 0.91 & 1.91 & Casual (B2) \\
\hline
\end{tabular}

\section{Discussion}

Integrating data on species range, abundance and per capita effect is a relatively new approach to determine the impact of invasive bee species. This approach allowed us to disentangle the relative weight of population size and individual effects to show that the impact of non-native bees on native bee communities seem to come from their large numbers and spread rather than the per capita effect. We encourage other researchers to obtain data that fit in the integrative formula proposed by Parker et al. (1999) in order to improve our understanding of how each one of the factors affects the overall invasion process itself. This flexible approach to measure impact can take many forms with different metrics for per capita effect (e.g. pollination rate, aggressive behavior and pollen removal) that are directly comparable across sites and species and that can be easily scaled up to include a larger region or number of populations or down to examine the effects of bees on individual plant species.

None of the non-native bees structurally change the native bee community, as observed by the per capita values, so it is presumable that none of them compete with the native bees for resource. According to a recent study carried out in Michigan (USA), despite the fact that non-native bees were positively correlated with urbanization, their success was not related with the decrease of native bees (Fitch et al., 2019). However, trial studies on competition should be carried out for a better understanding of this issue, as pointed out by Goulson (2003). 
Furthermore, there are two important factors potentially mediating the values observed here. Firstly, $A$. mellifera and $A$. manicatum are present in the region for at least several decades and it is possible that their greatest impact may have occurred during the first years of establishment and invasion. Studies assessing bee communities prior and post arrival of $A$. mellifera showed important changes in native bee community structure soon after the arrival of the species (e.g. Valido et al., 2019). Secondly, urbanization in the area has been shown to dramatically affect native bee communities with pronounced declines in bee richness and abundance over the past 40 years (Taura and Laroca, 2001; Martins et al., 2013; Cardoso and Gonçalves, 2018). It is possible that urbanization and non-native species residence time may be synergistically acting as regulators of native bee current community structure and dynamic.

The integrative impact approach gives a good measure to the unified framework proposed by Blackburn et al. (2011). In this study A. mellifera got a high impact value mainly because it was recorded in all sampled sites and also for having high abundance in the Airport samples. This data, combined from literature records of dense populations of honeybees almost all over the Americas (Schneider et al., 2004; Moure, 2012; Santos and Mendes, 2016), provide enough support to consider A. mellifera a fully invasive species in category $\mathrm{E}$. This means that it has transposed all the barriers of the invasion process: captivity or cultivation (introduction), survival and reproduction (establishment), dispersal and environmental spread (Blackburn et al., 2011). Despite the difficulty to address the impact of honeybees on wild bees (Moritz et al., 2005), several studies show the multiple risks that $A$. mellifera offers to native fauna, especially in sites close to large apiaries (Santos et al., 2012; Cane and Tepedino, 2017; Geldmann and González-Varo, 2017; Valido et al., 2019). The State of Paraná Environmental Institute already considers the honeybee as invasive in the category of "useful species under specific regulations" (IAP, 2015).

It is possible to directly compare the impact values of $A$. manicatum (3.94) and M. scutellaris (1.91) as we used the same sample and analytical methodology. This difference in values largely results from the fact that the first species occurred in three sites whereas the second in just one. The range of $A$. manicatum reflects its capacity to be actually established in the city of Curitiba, as it is a solitary bee that is not kept in cultivation. Also, historical data shows that this species is broadly distributed in eastern Brazil (Fig. 1c), and that it has been in the country since the beginning of the $20^{\text {th }}$ Century (Schrottky, 1903), being present in Curitiba at least since the 1940s (Moure, 1943). Although registered in different sites around the country, there are no records of large populations of A. manicatum, as corroborated with the data of this survey. In fact, it has not been sampled in Curitiba after 1965 (unpublished data from DZUP; Taura and Laroca, 2001; Martins et al., 2013; Cardoso and Gonçalves, 2018). This new information enables us to classify $A$. manicatum as invasive under the category D2 (self-sustaining population distant from introduction point). This means that it has overcome all the invasion process barriers, but that it has not thrived so intensely, probably because of its solitary behavior and restricted floral resources it utilizes in the places it is established in the country. Furthermore, as described by Strange et al. (2011), the poor predictive capability of the South American invasive models of $A$. manicatum may be guided by the availability of floral resources found in urban gardens rather than by bioclimatic variables. Nevertheless, because of the fact that A. manicatum is a non-native species, the Paraná State Environmental Institute considers it in the category of "forbidden transport, cultivation, propagation and commercialization" (IAP, 2015).

With respect to the floral resources, $A$. manicatum was found only at $L$. japonicus (Lamiaceae), the same plant species from the first records of this bee in São Paulo (Schrottky, 1903), at that time erroneously recorded as L. sibiricus Linnaeus, 1758 (see Harley and Paton, 2001). Interestingly, L. japonicus is also a non-native species, originally from Asian and Mediterranean countries (Duarte and Lopes, 2005). Although also less recorded on Anthirrhinum majus (Lamiales, Plantaginaceae) and Duranta repens L. (Verbenaceae) (Moure and Urban, 1964; BBPID), the reliance of $A$. manicatum on L. japonicus may suggest that the persistence and spread of this bee species may be the result of an invasional meltdown (Simberloff and Von Holle, 1999). Invasional meltdown occurs when nonindigenous species can facilitate one another's invasion in various ways, including pollination and plant dispersion. However, L. japonicus can also be a resource for native bees and help to support local pollinators (Lowenstein et al., 2018).

M. scutellaris was detected at only one location and thus considered just a casual alien species (B2, in cultivation). It was probably transported to Curitiba for breeding purposes, and is maintained by beekeepers in rational hives with heating system (unpubl. data). A modelling study suggested that $M$. scutellaris has low probability to occur in the Curitiba region in the next century even with climate change (Giannini et al., 2012) but further monitoring or controlled experiments would be required for a proper evaluation of the potential of the species to stablished self-sustaining populations in the wild and become invasive in the region. As a generalist species (Souza et al., 2015; BBPID) with a considerably long flight ranges (Araújo et al., 2004), M. scutellaris has potential to invade warmer regions of the country. In fact, data from SpeciesLink (Fig. 1e) show its current distribution in the Midwest and Southeastern Brazil, areas where it should be monitored for its potential to become invasive. After 2017, the meliponiculture in Paraná started to be regulated by Law (Law Number 19152) (Paraná, 2017), which forbids the introduction, breeding and commercialization of M. scutellaris in the State (MMA, 2004; Paraná, 2017).

The enthusiasm on Meliponini beekeeping as a hobby, including within the cities, and also for honey production, can be negative to conservation when decoupled with scientific knowledge, especially in terms of species introduction and hybridization. The vulnerable and endangered species have its own pressures as deforestation increases and climate change, and their conservation is not necessarily linked to the beekeeping practices outside of their natural distributional range. In Curitiba, eight native species can be used for meliponiculture: Melipona bicolor schencki Gribodo, 1893, Melipona marginata Lepeletier, 1836, M. quadrifasciata, Plebeia droryana (Friese, 1900), Plebeia emerina (Friese, 1900), Plebeia remota (Holmberg, 1903), Scaptotrigona bipunctata (Lepeletier, 1836) and Tetragonisca fiebrigi (Schwarz, 1938) (Laroca, 1974; Barbola and Laroca, 1993; Cardoso and Gonçalves, 2018). Stingless beekeeping should be economic and but also ecological viable (Venturieri et al., 2012).

Further additional information about competition, predation, hybridization, transmission of diseases and parasitism, would be useful for helping us to classify these non-native bees under the unified classification of alien species based on the magnitude of their environmental impacts proposed by Blackburn et al. (2014). After Blackburn et al. (2014), other researchers have outlined the importance of the classes of impact to help us globally monitor non-native species (Hawkins et al., 2015; Latombe et al., 2017). For those found in Curitiba, literature data demonstrates that $M$. scutellaris can hybridize with its closest related species (Nascimento et al., 2000) and that $A$. mellifera transmit diseases to other bees (Fürst et al., 2014). But a precise classification can only be done with a more refined research to fill all gaps of impact criteria proposed here. 


\section{Conclusions}

By disentangling the ecological impact of the non-native bee species currently occuring in Curitiba by their range, abundance and per capita effect, we were able to measure the relative weight of each of them. None of the species structurally changed the native bee community, as observed by their per capita values. A. mellifera showed a high impact value because it was recorded in all studied sites and also for having high abundance everywhere, which, coupled with literature data of its distributional records, can be considered a fully invasive species in the category E according to Blackburn et al. (2011). A. manicatum and M. scutellaris did not occurred in all sampled sites and both had low abundance values, which, coupled with literature data, gave us support to consider them, in the studied area, in the category D2 (self-sustaining population distant from introduction point) and B2 (in cultivation) respectively.

As pointed out by Goulson (2004), unlike many of the other impacts that man has done on the environment, introduction of alien species is usually irreversible, so the precautionary principle for biological invasions recommends the continuous monitoring of the species in the urban environment. A. manicatum and its host plant $L$. japonicus should be monitored in the city parks for possible changes in bee and plant populations and impact on the native biota. Beekeeping should prioritize native bees, at least inside and around urban areas, and the feral honeybee populations should be monitored. We suggest that the risks of beekeeping non-native stingless bees should reverberate to beekeepers to avoid future introduction and associated risks. The gap between bee research and beekeeping is a good example of the weak link between academia and society in Brazil.

\section{Acknowledgements}

We thank Camila Costa, Felipe Walter Pereira and Gabriel Melo for literature indication and comments about non-native species. We are indebted with Renato Goldenberg for plant species identification. We are grateful to Ministério do Meio Ambiente, Exército Brasileiro, Infraero and Secretaria do Meio Ambiente de Curitiba for research authorizations.

\section{Funding}

This study was funded by the Conselho Nacional de Desenvolvimento Científico e Tecnológico (grant number 142068/2016-0).

\section{Conflict of interest}

The authors declare that they have no conflict of interest.

\section{Compliance with ethical standards}

All procedures performed in this study were in accordance with the ethical standards and legislation of the institutions and sites where it was conducted.

\section{Authors Contribution}

LVG, RDZ and RBG conceived this research and participated in the writings and revisions of it as well as in the interpretation of the data; LVG did the samplings; RDZ performed the analysis. All authors read and approved the final manuscript.

\section{References}

Aizen, M. A., Smith-Ramírez, C., Morales, C. L., Vieli, L., Sáez, A., BarahonaSegovia, R. M., Arbetman, M. P., Montalva, J., Garibaldi, L. A., Inouye, W., Harder, L. D., 2018. Coordinated species importation policies are needed to reduce serious invasions globally: the case of non-native bumblebees in South America. J. Appl. Ecol. 56 (1), 100-106. http:// dx.doi.org/10.1111/1365-2664.13121.

Alves, R. M. O., Carvalho, C. A. L., Souza, B. A., Santos, W. S., 2012. Areas of natural occurrence of Melipona scutellaris Latreille, 1811 (Hymenoptera: Apidae) in the state of Bahia, Brazil. An. Acad. Bras. Cienc. 84 (3), 679-688. http://dx.doi.org/10.1590/S000137652012000300010.

Araújo, E. D., Costa, M., Chaud-Netto, J., Fowler, H. G., 2004. Body size and flight distance in stingless bees (Hymenoptera: Meliponini): inference of flight range and possible ecological implications. Braz. J. Biol. 64 (3b), 563-568. http://dx.doi.org/10.1590/S151969842004000400003.

Barbola, I. F., Laroca, S., 1993. A comunidade de Apoidea (Hymenoptera) da Reserva Passa Dois (Lapa, Paraná, Brasil) I. Diversidade, abundância relativa e atividade sazonal. Acta Biol. Parana. 22, 91-113. http:// dx.doi.org/10.5380/abpr.v22i0.730.

Blackburn, T. M., Essl, F., Evans, T., Hulme, P. E., Jeschke, J. M., Kühn, I., Kumschick, S., Marková, Z., Mrugała, A., Nentwig, W., Pergl, J., Pyšek, P., Rabitsch, W., Ricciardi, A., Richardson, D. M., Sendek, A., Vilà, M., Wilson, J. R. U., Winter, M., Genovesi, P., Bacher, S., 2014. A unified classification of non-native species based on the magnitude of their environmental impacts. PLoS Biol. 12 (5), e1001850. http://dx.doi. org/10.1371/journal.pbio.1001850.

Blackburn, T. M., Pyšek, P., Bacher, S., Carlton, J. T., Duncan, R. P., Jarošík, V., Wilson, J. R. U., Richardson, D. M., 2011. A proposed unified framework for biological invasions. Trends Ecol. Evol. 26 (7), 333339. http://dx.doi.org/10.1016/j.tree.2011.03.023.

Camargo, J. M. F., Pedro, S. R. M., 2013. Meliponini Lepeletier, 1836. In: Moure, J.S., Urban, D., Melo, G.A.R. (Eds.), Catalogue of Bees (Hymenoptera, Apoidea) in the Neotropical Region. Sociedade Brasileira de Entomologia, Curitiba. Available in: http://www.moure. cria.org.br/catalogue/ (accessed 26 November 2019).

Cane, J. H., Tepedino, V. J., 2017. Gauging the effect of honey bee pollen collection on native bee communities. Conserv. Lett. 10 (2), 205-210. http://dx.doi.org/10.1111/conl.12263.

Cardoso, M. C., Gonçalves, R. B., 2018. Reduction by half: the impact on bees of 34 years of urbanization. Urban Ecosyst. 21 (5), 943-949. http://dx.doi.org/10.1007/s11252-018-0773-7.

Deguines, N., Julliard, R., Flores, M., Fontaine, C., 2016. Functional homogenization of flower visitor communities with urbanization. Ecol. Evol. 6 (7), 1967-1976. http://dx.doi.org/10.1002/ece3.2009.

Didham, R. K., Tylianakis, J. M., Gemmell, N. J., Rand, T. A., Ewers, R. M., 2007. Interactive effects of habitat modification and species invasion on native species decline. Trends Ecol. Evol. 22 (9), 489-496. http:// dx.doi.org/10.1016/j.tree.2007.07.001.

Dormann, C. F., Gruber, B., Fruend, J., 2008. Introducing the bipartite package: analyzing ecological networks. R News 8, 8-11.

Duarte, M. D. R., Lopes, J. F., 2005. Morfoanatomia foliar e caulinar de Leonurus sibiricus L., Lamiaceae. Acta Farm Bonaer. 24, 68-74.

Evangelista-Rodrigues, A., Silva, E. M. S., Beserra, E. M. F., Rodrigues, M. L., 2005. Análise físico-química dos méis das abelhas Apis mellifera e Melipona scutellaris produzidos em regiões distintas no Estado da Paraíba. Cienc. Rural 35 (5), 1166-1171. http://dx.doi.org/10.1590/ S0103-84782005000500028.

Ferreira, P. A., Boscolo, D., Carvalheiro, L. G., Biesmeijer, J. C., Rocha, P. L. B., Viana, B. F., 2015. Responses of bees to habitat loss in fragmented 
landscapes of Brazilian Atlantic Rainforest. Landsc. Ecol. 30 (10), 2067-2078. http://dx.doi.org/10.1007/s10980-015-0231-3.

Fitch, G., Wilson, C. J., Glaum, P., Vaidya, C., Simao, M. C., Jamieson, M. A., 2019. Does urbanization favour exotic bee species? Implications for the conservation of native bees in cities. Biol. Lett. 15 (12), 20190574. http://dx.doi.org/10.1098/rsbl.2019.0574.

Fragkias, M., Lobo, J., Strumsky, D., Seto, K. C., 2013. Does size matter? Scaling of CO2 emissions and US urban areas. PLoS One 8 (6), 1-8. http://dx.doi.org/10.1371/journal.pone.0064727.

Freitas, B. M., Imperatriz-Fonseca, V. L., Medina, L. M., Kleinert, A. M. P., Galetto, L., Nates-Parra, G., Quezada-Euán, J. J. G., 2009. Diversity, threats and conservation of native bees in the Neotropics. Apidologie 40 (3), 332-346. http://dx.doi.org/10.1051/apido/2009012.

Fürst, M. A., McMahon, D. P., Osborne, J. L., Paxton, R. J., Brown, M. J. F., 2014. Disease associations between honeybees and bumblebees as a threat to wild pollinators. Nature 506 (7488), 364-366. http:// dx.doi.org/10.1038/nature12977.

Geldmann, J., González-Varo, J. P., 2017. Conserving honey bees does not help wildlife. Science 359 (6374), 392-393. http://dx.doi. org/10.1126/science.aar2269.

Giannini, T. C., Acosta, A. L., Garófalo, C. A., Saraiva, A. M., Alves-dos-Santos, I., Imperatriz-Fonseca, V. L., 2012. Pollination services at risk: bee habitats will decrease owing to climate change in Brazil. Ecol. Modell. 244, 127-131. http://dx.doi.org/10.1016/j.ecolmodel.2012.06.035.

Gibbs, J., Sheffield, C. S., 2009. Rapid Range Expansion of the WoolCarder Bee, Anthidium manicatum (Linnaeus) (Hymenoptera: Megachilidae), in North America. J. Kans. Entomol. Soc. 82 (1), 21-29. http://dx.doi.org/10.2317/JKES805.27.1.

Goulson, D., 2003. Effects of introduced bees on native ecosystems. Annu. Rev. Ecol. Evol. Syst. 34 (1), 1-26. http://dx.doi.org/10.1146/ annurev.ecolsys.34.011802.132355.

Goulson, D., 2004. Keeping bees in their place: impacts of bees outside their native range. Bee World 85 (3), 45-46. http://dx.doi.org/10.1 080/0005772X.2004.11099622.

Graham, K. K., Eaton, K., Obrien, I., Starks, P. T., 2019. Anthidium manicatum, an invasive bee, excludes a native bumble bee, Bombus impatiens, from floral resources. Biol. Invasions 21 (4), 1089-1099. http://dx.doi.org/10.1007/s10530-018-1889-7.

Harley, R., Paton, A., 2001. Leonurus japonicus Houtt. (Labiatae): the correct name for a common tropical weed. Kew Bull. 56 (1), 243244. http://dx.doi.org/10.2307/4119443.

Hawkins, C. L., Bacher, S., Essl, F., Hulme, P. E., Jeschke, K. M., Kühn, I., Kumschick, S., Nentwig, W., Pergl, J., Pyšek, P., Rabitsch, W., Richardson, D. M., Vilà, M., Wilson, J. R. U., Genovesi, P., Blackburn, T. M., 2015. Framework and guidelines for implementing the proposed IUCN Environmental Impact Classification for Alien Taxa (EICAT). Divers. Distrib. 21 (11), 1360-1363. http://dx.doi.org/10.1111/ddi.12379.

IAP, 2015. Portaria no 059, 9, de 15 de abril de 2015. Diário Oficial do Município, Curitiba. Available in: http://www.iap.pr.gov.br/ arquivos/File/Lista_invasoras_PR_corrigida_set_2015.pdf/ (accessed 30 January 2019).

IBGE, 2017. Available in: https://cidades.ibge.gov.br/brasil/pr/curitiba/ panoram/ (accessed 25 August 2018).

ICMBio, 2016. Sumário executivo do livro vermelho da fauna brasileira ameaçada de extinção. Available in: http://www.icmbio.gov.br/ portal/ (accessed 04 March 2019).

Kowarik, I., 2011. Novel urban ecosystems, biodiversity, and conservation. Environ. Pollut. 159 (8-9), 1974-1983. http://dx.doi.org/10.1016/j. envpol.2011.02.022.

Laroca, S., 1974. Estudo feno-ecológico em Apoidea do litoral e primeiro planalto Paranaense. Curitiba, Universidade Federal do Paraná, 62pp.
Latombe, G., Pyšek, P., Jeschke, J. M., Blackburn, T. M., Bacher, S., Capinha, C., Costello, M. J., Fernández, M., Gregory, R. D., Hobern, D., Hui, C., Jetz, W., Kumschick, S., McGrannachan, C., Pergl, J., Roy, H. E., Scalera, R., Squires, Z. E., Wilson, J. R. U., Winter, M., Genovesi, P., McGeoch, M. A., 2017. A vision for global monitoring of biological invasions. Biol. Conserv. 213, 295-308. http://dx.doi.org/10.1016/j. biocon.2016.06.013.

Lowenstein, D. M., Matteson, K. C., Minor, E. S., 2018. Evaluating the dependence of urban pollinators on ornamental, non-native, and ‘weedy’ floral resources. Urban Ecosyst. 22 (2), 293-302. http:// dx.doi.org/10.1007/s11252-018-0817-z.

Martins, A. C., Gonçalves, R. G., Melo, G. A. R., 2013. Changes in wild bee fauna of a grassland in Brazil reveal negative effects associated with growing urbanization during the last 40 years. Zoologia 30 (2), 157-176. http://dx.doi.org/10.1590/S1984-46702013000200006.

Michener, C. D., 2007. The Bees of the World. The Johns Hopkins University Press, Baltimore.

Miller, S. R., Gaebel, R., Mitchell, R. J., Arduser, M., 2002. Occurrence of two species of old world bees, Anthidium manicatum and A. oblongatum (Apoidea: Megachilidae), in northern Ohio and southern Michigan. Great Lakes Entomol. 35, 65-69.

Ministério do Meio Ambiente - MMA, 2004. Resolução Conama nº 346, de 16 de agosto de 2004. Diário Oficial da União, Brasília.

Moritz, R. F. A., Härtel, S., Neumann, P., 2005. Global invasions of the western honeybee (Apis mellifera) and the consequences for biodiversity. Ecoscience 12 (3), 289-301. http://dx.doi.org/10.2980/ i1195-6860-12-3-289.1.

Moure, J. S., 2012. Apini Latreille, 1802. In: Moure, J.S., Urban, D., Melo, G.A.R. Catalogue of Bees (Hymenoptera, Apoidea) in the Neotropical Region. Sociedade Brasileira de Entomologia, Curitiba. Available in: http://www.moure.cria.org.br/catalogue/ (accessed 18 March 2019).

Moure, J. S., 1943. Abelhas de Batatais. Arq. Mus. Parana. 3, 145-205.

Moure, J. S., Urban, E. D., 1964. Revisão das espécies brasileiras de gênero Anthidium Fabricius, 1804. In: Congresso Latino-Americano de Zoologia, 2, 1964, São Paulo. Anais. Vol. 1. São Paulo: Departamento de Zoologia, Secretaria da Agricultura de São Paulo, pp. 93-114.

Nascimento, V. A., Matusita, S. H., Kerr, W. E., 2000. Evidence of hybridization between two species of Melipona bees. Genet. Mol. Biol. 23 (1), 79-81. http://dx.doi.org/10.1590/S1415-47572000000100014.

Paini, D. R., 2004. Impact of the introduced honey bee (Apis mellifera) (Hymenoptera: Apidae) on native bees: a review. Austral Ecol. 29 (4), 399-407. http://dx.doi.org/10.1111/j.1442-9993.2004.01376.x.

Paraná, 2017. Lei oํ 19152, de 2 de outubro de 2017. Dispõe sobre a criação, o manejo, o comércio e o transporte de abelhas sociais nativas (meliponíneos). Diário Oficial do Estado, Curitiba. Available in: https://www.legislacao.pr.gov.br/legislacao/pesquisarAto. do ?action=listarandopt=randsite $=1 \#$ resultado $/$ (accessed 12 December 2018).

Parker, I. M., Simberloff, D., Lonsdale, W. M., Goodell, K., Wonham, M., Kareiva, P. M. M., Williamson, H., Von Holle, B., Moyle, P. B., Byers, J. E., Goldwasser, L., 1999. Impact: toward a framework for understanding the ecological effects of invaders. Biol. Invasions 1 (1), 3-19. http://dx.doi.org/10.1023/A:1010034312781.

Pitts-Singer, T. L., Cane, J. H., 2011. The alfalfa leafcutting bee, Megachile rotundata: the world's most intensively managed solitary bee. Annu. Rev. Entomol. 56 (1), 221-237. http://dx.doi.org/10.1146/ annurev-ento-120709-144836.

Russo, L., 2016. Positive and negative impacts of non-native bee species around the world. Insects 7 (4), 1-22. http://dx.doi.org/10.3390/ insects7040069. 
Sakagami, S. F., Laroca, S., Moure, J. S., 1967. Wild bee biocoenotics in São José dos Pinhais (PR), south Brazil. Preliminary Rep. J. Fac. Sci. 16, 253-291.

Santos, A. M. M., Mendes, E. C., 2016. Abelha africanizada (Apis mellifera L.) em áreas urbanas no Brasil: necessidade de monitoramento de risco de acidentes. Sustinere. 4 (1), 117-143. http://dx.doi. org/10.12957/sustinere.2016.24635.

Santos, G. M. M., Aguiar, C. M. L., Genini, J., Martins, C. F., Zanella, F. C. V., Mello, M. A. R., 2012. Invasive Africanized honeybees change the structure of native pollination networks in Brazil. Biol. Invasions 14, 2369-2378. http://dx.doi.org/10.1007/s10530-012-0235-8.

Schneider, S. S., DeGrandi-Hoffman, G., Smith, D. R., 2004. The African honey bee: factors contributing to a successful biological invasion. Annu. Rev. Entomol. 49 (1), 351-376. http://dx.doi.org/10.1146/ annurev.ento.49.061802.123359.

Schrottky, C., 1903. Biologische Notizen solitarer Bienen von S. Paulo (Brasilien). Allg. Z. Entomologie. 6, 209-216.

Silva, D. P., Gonzalez, V. H., Melo, G. A. R., Lucia, M., Alvarez, L. J., De Marco Junior, P., 2014. Seeking the flowers for the bees: integrating biotic interactions into niche models to assess the distribution of the exotic bee species Lithurgus huberi in South America. Ecol. Modell. 273, 200-209. http://dx.doi.org/10.1016/j. ecolmodel.2013.11.016.

Silveira, F. A., Melo, G. A. R., Campos, L. A. O., 2008. Melipona capixaba Moure and Camargo, 1995. In: Machado, A.B.M., Drummond, G.M., Paglia, A.P. (Eds.), Livro vermelho da fauna brasileira ameaçada de extinção. Instituto Chico Mendes de Conservação da Biodiversidade, Brasília, pp. 60-61.

Simberloff, D., Martin, J.-L., Genovesi, P., Maris, V., Wardle, D. A., Aronson, J., Courchamp, F., Galil, B., García-Berthou, E., Pascal, M., Pyšek, P., Sousa, R., Tabacchi, E., Vilà, M., 2013. Impacts of biological invasions: what's what and the way forward. Trends Ecol. Evol. 28 (1), 58-66. http://dx.doi.org/10.1016/j.tree.2012.07.013.

Simberloff, D., Von Holle, B., 1999. Positive interactions of nonindigenous species: invasional meltdown? Biol. Invasions 1 (1), 21-32. http:// dx.doi.org/10.1023/A:1010086329619.

Souza, L. S., Lucas, C. I. S., Conceição, P. D. J., Paixão, J. F., Alves, R. M. O., 2015. Pollen spectrum of the honey of uruçu bee (Melipona scutellaris Latreille, 1811) (Hymenoptera: Apidae) in the north coast of Bahia state. Acta Sci. Biol. Sci. 37 (4), 483-489. http://dx.doi.org/10.4025/ actascibiolsci.v37i4.28059.

Strange, J. P., Koch, J. B., Gonzalez, V. H., Nemelka, L., Griswold, T., 2011. Global invasion by Anthidium manicatum(Linnaeus) (Hymenoptera:
Megachilidae): assessing potential distribution in North America and beyond. Biol. Invasions 13 (9), 2115-2133. http://dx.doi.org/10.1007/ s10530-011-0030-y.

Taura, H. M., Laroca, S., 2001. A associação de abelhas silvestres de um biótopo urbano de Curitiba (Brasil), com comparações espaçotemporais: abundância relativa, fenologia, diversidade e explotação de recursos (Hymenoptera, Apoidea). Acta Biol. Parana. 30, 35-137. http://dx.doi.org/10.5380/abpr.v30i0.599.

Todesco, M., Pascual, M. A., Owens, G. L., Ostevik, K. L., Moyers, B. T., Hübner, S., Heredia, S. M., Hahn, M. A., Caseys, C., Bock, D. G., Rieseberg, L. H., 2016. Hybridization and extinction. Evol. Appl. 9 (7), 892-908. http://dx.doi.org/10.1111/eva.12367.

United Nations, 2018. Available in: https://www.un.org/development/ desa/en/news/population/world-population-prospects-2017.html/ (accessed 3 December 2018).

Urban, D., Moure, J. S., 2012. Anthidiini Ashmead, 1899. In: Moure, J.S., Urban, D., Melo, G.A.R. (Eds.), Catalogue of Bees (Hymenoptera, Apoidea) in the Neotropical Region. Sociedade Brasileira de Entomologia, Curitiba. Available in: http://www.moure.cria.org. br/catalogue/ (accessed 4 February 2019).

Valido, A., Rodríguez-Rodríguez, M. C., Jordano, P., 2019. Honeybees disrupt the structure and functionality of plant-pollinator networks. Sci. Rep. 9(1), 1-11. http://dx.doi.org/10.1038/s41598-019-41271-5.

Van Engelsdorp, D., Evans, J. D., Saegerman, C., Mullin, C., Haubruge, E., Nguyen, B. K., Frazier, M., Frazier, J., Cox-Foster, D., Chen, Y., Underwood, R., Tarpy, D. R., Pettis, J. S., 2009. Colony collapse disorder: a descriptive study. PLoS One 4 (8), e6481. http://dx.doi. org/10.1371/journal.pone.0006481.

Venturieri, C. G., Alves, D. A., Villas-Bôas, J. K., Carvalho, C. A. L., Menezes, C., Vollet-Neto, A., Contreta, F. A. L., Cortopassi-Laurino, M., NogueiraNeto, P., Imperatriz-Fonseca, V. L., 2012. Meliponicultura no Brasil: situação atual e perspectivas futuras para o uso na polinização agrícola. In: Imperatriz-Fonseca, V.L., Canhos, D., Alves, D.A., Saraiva, A.M. (Eds.), Polinizadores no Brasil: contribuição e perspectivas para a biodiversidade, uso sustentável, conservação e serviços ambientais. Edusp, São Paulo, pp. 213-230.

Wolf, E. D., Takebayashi, N., Rieseberg, L. H., 2001. Predicting the risk of extinction through hybridization. Conserv. Biol. 15 (4), 1039-1053. http://dx.doi.org/10.1046/j.1523-1739.2001.0150041039.x.

Zonta, A.C., Figueiredo, A.S., Dalco, V.S., 2012. Caracterização da fragilidade ambiental de Curitiba - PR utilizando geoprocessamento. In: Simpósio de Geotecnologias no Pantanal, 4, 2012, Bonito, MS, Brasil. Anais. Brasília: Embrapa, pp. 28-38.

\section{Supplementary material}

The following online material is available for this article:

Table S1 - Sampled sites and its geographical coordinates.

Table S2 - A complete list of individual bees sampled in the six host plants. Table S3 - Information about host plants, bee species, bee sex, the sites where the bees were collected with its respective dates, as well as its geographical coordinates. 